\title{
Guest editorial procuring academics for empire: the pentagon minerva research initiative
}

\author{
James Petras
}

Published online: 29 April 2009

(C) Springer Science+Business Media B.V. 2009

The Pentagon's military strategists have recognized that they have suffered political losses, with strategic consequences in their recent military invasions of Iraq and Afghanistan. US military support for the Israeli invasions of Lebanon and Gaza, the US-sponsored Ethiopian occupation of Somali, the coup attempts in Venezuela (2002) and Bolivia (2008), have also failed to defeat popular incumbent regimes. Worse still, civilian, family, community, and national networks have reinforced the anti-colonial movements providing essential logistical support, intelligence, recruits, and legitimacy.

Pentagon strategists, recognizing the socio-political bases of their failures, have turned to willing accomplices in the academic world to provide intelligence, in the form of ethnographic accounts of targeted peoples, tactics and strategies in order to divide and destroy local and national loyalties. The Pentagon is contracting social scientists to develop 'social maps' to identify leaders and groups, susceptible to recruitment in the service of the empire. For example, Pentagon-contracted academic 'field research' is designed to demonstrate ways in which traditional religious practices and rituals can be harnessed to facilitate imperial conquest through cultural warfare discouraging subjugated peoples from giving their support to national liberation movements. Rather than confront the imperial occupier with a goal of re-establishing national sovereignty, 'cultural warfare' strategies direct people to focus on 'local concerns'. These are a few of the Pentagon-funded "research projects" taken up by the 'academics in uniform.'

The Pentagon is seriously engaged in this military-academic empire building strategy, allocating almost 100 million dollars to contracting academic collaborators

James Petras is a freelance writer working with landless workers in Brazil.

J. Petras $(\bowtie)$

Department of Sociology, State University of New york, Binghamton, NY, USA

e-mail: jpetras@binghamton.edu 
and funding multiple 'research' projects throughout the world against targeted states, movements, and communities.

\section{The "Minerva Research Initiative" (MRI)}

The biggest, but not the only, Pentagon-funded empire building research program in the social sciences is dubbed the Minerva Research Initiative (MRI). The MRI has contracted scores of academics from the usual prestigious academic brothels, including the veteran academic hookers and ambitious neophytes among postdoctorates and graduate assistants. These 'scholars for empire' are currently engaged in at least fourteen projects.

MRI money has attracted a wide assortment of university affiliated psychologists, political scientists, anthropologists, economists, professors of religious studies, public affairs specialists, labor economists, and even nuclear physicists from MIT, Princeton, University of California at San Diego, and Arizona State University among others. This Pentagon largess provides what Science (the official journal of the American Association for the Advancement of Science) calls a "banquet for a field accustomed to living on scraps." (Mervis 2009)

All of the regions and groups specifically targeted for the 'Pentagon-academic' investigation are currently in conflict with the US empire or its Israeli ally and include Southwest Asia, West Africa, Gaza, Indonesia, and the Middle East. The Pentagon's ideological parameter, which defines the MRI, is the "war on terror," or "Overseas Contingency Operations", its new facsimile under President Obama.

The MRI has a special interest in academics who can target the field of MuslimArab organizations and activities, in order to study and develop methods to "diffuse and influence counter-radical Muslim discourse." ${ }^{1}$ In other words, the MRI is contracting academic research, which will allow the Pentagon to penetrate Muslim communities, co-opt the leaders and turn them into imperial collaborators.

MRI is not merely a mechanism of "soft power" — a battle of ideas-it engages US academics in some of the more brutal aspects of colonial warfare. For example, the Pentagon-funded Human Terrain Teams (HTT), which operate in Afghanistan, are deeply immersed in the identification and torture/interrogation of suspected resistance fighters, civilian sympathizers, and members of extended families and clans. One San Francisco State psychology professor on the MRI payroll, with longstanding ties to Pentagon counter-insurgency operations, is deeply involved in the "study of emotions in stoking or quelling ideologically driven movements." 2

Covert occupation intelligence operations have been deeply involved in "stoking" hostility between Shia and Sunni communities in Iraq, Lebanon, Iran, and Afghanistan. Torture and harsh interrogation techniques, used in the Middle East and Afghanistan, are based on academic studies of cultural and emotional vulnerabilities of Muslims and are used by US and Israeli military interrogators to

\footnotetext{
1 Ibid.

2 Ibid., p. 577.
} 
"break" or cause profound mental breakdown of anti-occupation activists ("quelling ideological movements").

Two US professors who solicited and secured major funding under MRI, one Eli Berman of the University of California San Diego and Jacob Shapiro of Princeton are working with Israeli counter-insurgency academics in researching what it takes for the Jewish state to manipulate Palestinian communities "to counteract grassroots movements such as Hamas". 3

Berman and Shapiro have their own academic empire building ambitions, feeding off the Pentagon largesse and its military driven empire building. With the Pentagon money Berman claims "I'll be able to do surveys and experiments around the world, partner with additional organizations and bring postdocs as well as several graduate students. We'll be able to accomplish things in a matter of years rather than decades." 4

This contemporary version of Dr. Strangelove with his instant counterinsurgency formulas cooked up by a world network of academics in uniform can poison the academic ambience-in much the same way that the Professor 'Bermans' at Michigan State, MIT, Harvard and elsewhere developed techniques for search and destroy missions against grassroots movements during the Viet Nam War. The danger and appeal to academics of Pentagon funding is especially acute nowadays, given the economic depression and the pseudo-progressive image of the Obama regime. Wall Street bailouts and the crash of the US stock market have reduced university endowments resulting in sharp reductions in academic budgets, salaries and research funding especially on non-military, non-business related research. The Obama regime's double discourse of talking peace and escalating military budgets, increasing troops in Southwest Asia and extending sanctions on Iran may entice academics to justify the latter by citing the former. To procure academic recruits to the MRI stable, the Pentagon organized a workshop in August 2008, under the ideological façade of "complete openness and strict adherence to academic freedom and integrity." Subsequently the Pentagon claimed to have received 211 inquires from academics seeking a place at the imperial trough. ${ }^{5}$

Notwithstanding the Pentagon's claim of success in procuring academics, there are counter-signs appearing in the academic world, especially in light of the highly publicized kidnapping, torture, and interrogation of thousands of Muslims and activists throughout the world including the United States, by Special Forces.

Outside the far-right there has been a widespread reluctance among academics to be associated with a government identified with abuses at Abu Gharib and Guantanamo prisons, the shredding of the US Constitutional protections and open ended colonial wars of occupation.

Even in the case where powerful pro-Israel academics and lobbyists have successfully secured the dismissal of highly published professors critical of the Hebrew state, these vindictive purges were openly opposed by scores of professors around the country including several dozen Jewish academics. More recently,

\footnotetext{
3 Ibid.

4 Ibid.

5 Ibid.p. 576.
} 
hundreds of academics and researchers in the US, the United Kingdom, and Canada, horrified by the Israeli war crimes in Gaza, have called on universities to boycott Israeli academic institutions and individuals who collaborate with the Israeli Defense Forces and the Mossad in the destruction of Palestinian institutions especially the bombing of universities in Gaza.

The principled stand of academics critical of Israel and US policy notwithstanding, distinguished academics who have substantially challenged the empire through their research and publications are not immune from retaliation designed to discourage other intellectuals: A recent case in point is the suspension of academic medical epidemiologist, Dr. Gilbert Burnham of the Bloomberg School of Public Health at John Hopkins University.

Dr Burnham was publicly reprimanded and suspended from directing any research involving 'human subjects' for 5 years because of 'ethical breaches of confidentiality'. (Bohannon 2009) These 'ethical violations' referred to his coauthorship in the first scientific large-scale epidemiologic survey of mortality in Iraq during the US invasion and occupation where extensive site surveys found that upwards of 600,000 Iraqi civilians had died from violence between the time of the US invasion in March 2003 and the summer of 2006. The scale of the death and destruction published in the prestigious medical journal Lancet in October 2006 was denied by a furious Pentagon but confirmed by subsequent studies.

Dr. Burnham's 'ethical violations' referred to the incomplete coding of the names of the Iraqi families surveyed on the onsite Arabic language survey sheets. For institutions, like Johns Hopkins University, it is more important to 'protect' the privacy of the hundreds of thousands of nameless dead in a US war of aggression than to document the horrific effects of that war on human populations. By publicly punishing Dr. Burnham on these trumped up charges, the Pentagon-John Hopkins University are sending an unambiguous message to academics not to measure and reveal the real human costs of empire. The identity of those tortured or dispossessed on the basis of policies developed by the Minerva 'academics' will certainly be kept 'confidential' - and very likely hidden in mass graves.

We can expect the Obama regime, with its 'missiles for peace' rhetoric and populist images, will provide a cover for Pentagon recruitment of liberal academics to 'work for change from within.' Unmasking the role of the Pentagon's Minerva Research Initiative as an integral part of Obama's military escalation is a challenge to all academics who are opposed to empire building and who support the reconstruction of an American republic supportive of international rights of selfdetermination.

\section{References}

Mervis, Jeffrey. 2009. DOD funds new views on conflict with its first Minerva grants. Science 323 (30 January 2009) : 576.

Bohannon, John. 2009. Author of Iraqi deaths study sanctioned. Science 323 (March 6, 2009) : 1278. 